\title{
THE USE OF CONJOINT ANALYSIS IN STRATEGIC DECISION MAKING: AN INITIAL STUDY
}

\author{
Lina Anatan ${ }^{1}$ \\ ${ }^{1}$ Faculty of Economics, Universitas Kristen Maranatha Bandung \\ lina.anatan@eco.maranatha.edu
}

\begin{abstract}
In environment where change often comes through crises, disruptions and discontinuities, strategic decision making cannot be based on simple extrapolations of current situation. An organization can respond to crisis in variety ways through strategy implementation, such as turnaround strategy, liquidation strategy, and endgames strategy which have different attributes. By using Magister Management students as respondents, this initial study seeks to examine what strategy attributes and combination of strategy attributes are important to consider the strategy implementation in crisis. To produce the combination of strategy attributes that effect respondent's decision making to choose a strategy in crisis, conjoint analysis is used in this study. The result shows that the combination of strategy attributes such as risks, benefits, and policies are importants in affecting respondent's decision to implement strategy in crisis. Based on the statistical analysis, turnaround strategy which is reprenseted as reorganizational policy has become the most preffered strategy to respon crisis.

Keywords: Turnaround strategy, liquidation strategy, end-games strategy, decision making, organizational crisis.
\end{abstract}

\begin{tabular}{llll}
\hline JEL & $:$ D23 $;$ L10 & & \\
DOI & $: 10.24002 /$ kinerja.v22i1.1399 & \\
Received $: 10 / 01 / 2018$ & Reviewed $: 15 / 01 / 2018$ & Final Version : 28/02/2018 \\
\hline
\end{tabular}




\section{INTRODUCTION}

The fundamental issue in strategic management addresses the role of strategy in explaining why an organization performs better than any other organization. The performance variation can only be explained by the strategy that determined by how organization implements the strategy. Implementation of appropriate organizational strategy and decision making in response to existing business environment conditions is the key of organizational success to survive in the competition. Andrews (1971) and Chandler (1962) as cited in Fredrickson and Mitchell (1984) define organizational strategy and emphasize the concept of objectives, resource allocation, and planning. Based on this view, historically the organizational strategy is concluded as an integrated and statistically verifiable planning. According to Lin et al. (2014), organizational strategy defines as a way to ensure sustainable competitive advantage. It can be achieved through investing the resources needed to develop key capabilities which lead to long-term superior performance. Organizational strategy describes the suitability or alignment between external environment and internal structures and processes. The degree of alignment is the result of integrated strategy generated through a formal planning system created at a given time during a given year period. This perspective suggests that strategy formulation is decision-making process and needed for more productive research to study how organization develop individual strategic decisions and whether organization seek to integrate strategic decisions within the overall organizational strategy.

The role of strategic decision-making processes; especially in the actions taken, resources involved as a single unit in producing the right decisions according to the situation and conditions facing by the organization is important within organization (Mintzberg et al.,1976 as cited in Thomas,1984). Leadership has become the most important for strategic decision making to increase creativity (Buller, 2014). Strategic decision making related to managerial activity in all types of business organizations, large and small, profit and nonprofit, private and public organization. In all these of organizations types, managers are faced with the challenge of overcoming the difficulties and complexities of decision-making situations, such as decisions to enter new markets, developing new products, developing or closing businesses, enabling organizations to operate, adapt, grow, and benefit from opportunities and overcoming every challenge. Manager's ability to make this decision is crucial in contributing to the success of the organization.

Studies on strategic decision making provide an important insight into the role of rationality and bounded rational processes (Eisenhardt, 1989; Papadakis et al., 2010; Calabretta et al., 2017). Pettigrew (1973) as cited in Gu Seo and Barret (2007) suggests that rationality in decision making can not be easily understood without understanding the context in which the rationality of strategic decisions has a significant impact to the organization. Understanding the context in this case refers to the characteristics of decision makers, decision-specific characteristics, features of the external environment, and organization. In addition, external factors related to all aspects of public interest, especially in crisis conditions need to be considered in the decision-making process by considering whether the crisis is 
influenced by external or internal factors of the organization (Sommer \& Pearson, 2007; Elbanna \& Child, 2007; Elbanna et al., 2015).

According to Lilja et al. (2015), organizational strategy is influenced by both internal and external factors from both industry and firm-specific, and developed to suit the current and the future industry environment. Thompson (2007) classified organizational strategy in time of crisis within three strategic options, include: turnaround strategy, immediate abandonment strategy or liquidation strategy, and end-game strategy. Turnaround strategy aims to hold and sustain sources of competitive advantage and overcome financial weaknesses as quickly as possible. Liquidation strategy is out of competition either by selling the company to another organization or closing the business. While end-game strategies emphasize reinvestment to maximize cash flow in the short term to prepare out of the market. Each strategy has features in accordance with the objectives to be achieved. For example, turnaround process according to Smith and Graves (2005), the adoption of a turnaround strategy features the decline stemming strategy and recovery strategy. The factors of corporate health, firm size, and availability of free assets are predicted to influence the success of turnaround in the decline stemming cycle, and asset reduction factors, reduced employee numbers and CEO changes are predicted to affect turnaround in the recovery cycle. Another study conducted by Tansey and Spillane (2016) found that retrenchment is often considered to be a short-term strategy, however during the same period when internationalization has became critical aspect for the organization, turnaround shift towards the organization strategic reorientation.

In the strategic decision-making process, decision makers are not always able to make rational decisions due to bounded rationality and individual internal factors such as tastes and personalities that influence the preferences and decision making. Most of studies in strategic management, particularly on strategic decisionmaking under these time of crisis, focus on the influence of internal and external factors of the organization. This study focus on the role of rationality, taste, or personality that determines the decision-making preferences in the process of decision making to give real contribution to strategic management literature. In addition, attributes attached to the strategy should also be considered in strategic decision-making.

To find out the respondent's preference regarding attribute and combination of strategy attribute that influence their decision in choosing the implemented strategy, this study use conjoint analysis. The use of conjoint analysis in previous studies is more widely in marketing studies to determine consumer preferences for the various product options offered, and is very rarely used in strategic management research. The lack of conjoint analysis use in strategic decisionmaking process and the consideration of rationality, taste, or personality in determining decision maker's preference for implementing strategy under certain conditions, motivates researcher to study the application of conjoint analysis in strategic decision-making under crisis conditions. The research problems to be answered through the use of conjoint analysis in strategic decision making process 
include: 1) What typology of strategy is much preferred in time of crisis? 2) Which strategy feature has the most influential in the selection strategy in time of crisis?

In accordance with the benefits of conjoint analysis, this study aims to: (1) identify what typology of strategy is much preferred in crisis conditions, (2) determine which strategy feature has the most influential in the selection of strategies in time of crisis. This study is expected to give two main contributions; (1) Analyze the usefulness of conjoint analysis as an investigative approach to test strategic decision making in time of crisis, which is expected to make a significant contribution in the field of strategic management since conjoint analysis has been widely used in marketing research, and is still very rare to be implemented in the field of strategic management researches and (2) Analyze the decision-making process strategy to measure decision-making ability of respondents.

This paper is organized as follows. Part II discusses the literature review used as theoretical foundation in this study include the study of conceptual and empirical literature in strategic decision-making processes and the role of rationality of decision-makers in decision-making processes, and decision-making strategies in times of crisis. Part III discusses research methods that include: research samples and data collection research and data analysis techniques. Part IV presents empirical evidence of the data processing results on decision making in times of crisis using the conjoint analysis. Part $\mathrm{V}$ discusses the conclusion of the study result.

\section{LITERATURE REVIEW}

\subsection{Rationality in the Process of Strategic Decision Making}

Strategic decision making represents the essentials associated with action taken and the commitment of resources as a single entity in producing the right decisions according to the situation and conditions facing by the organization (Mintzberg et al., 1976 in Lohrke et al., 2004). McNulty and Pettigrew (1999) propose that members in the managerial team influence the decision-making process by forming ideas that shape the content of corporate strategy and the methodologies and processes by which ideas evolve. Study conducted by Wu et al. (2017) analyze top management team (TMT) characteristics and strategic decisionmaking. The study not only tested the mediating effects of risk perceptions and mental models, but also tested the moderating effects of psychological ownership. The study found that the mediating factors of risk perceptions and mental models are affected by the TMTs' characteristics and decision-making, and psychological owners moderate the relationship between TMTs' characteristics and decisionmaking.

Top management is an effective primary decision-maker based on the insights it has with respect to the work being handled and responsible for making a single decision when the organization is perceived to be under threat (Staw et al., 1981; Lohrke et al., 2004). Study conducted by Erena et al. (2014) investigate whether there is inuitive decision-making (which defined as leadership competencies) by top and middle managers. The study found that intuitive decision-making can be characterized by top and middle managers ability to 
recognize emotions, to reflect on options when making a decision, and also by making a decision at the last moment. Wong et al. (2011) examine the influence of TMTs integrative complexity and decentralization of decision making on corporate social performance. Using a Q-sort methodology, the study findings indicate that firms with TMTs characterized by higher integrative complexity have higher corporate social performance than do those characterized by lower levels of integrative complexity. The study also found that more decentralized firms have higher corporate social performance than more centralized firms (Wong et al., 2011). The strategic decisions made must be able to answer two main questions: (1) what industry is involved in the company and (2) how the company must compete in the industry.

Empirical studies of strategic decision making examine the influence of internal and external factors on the decision-making process. Internal influences on the decision-making process include decision-making goals (Westbrook et al., 2012), decision situations and context (Bamiatzi \& Kirchmaier, 2014; Robbinson et al., 2017), knowledge (Litvaj \& Stancekova, 2015), emotions (Morrish, 2012; Fox, 2015), decision-making characteristics such as information (Maxwell et al., 2015), organizational and resource capabilities (O'Regan et al., 2011; Barbero et al., 2012), culture organizations (Dabic et al., 2015), and individual behavior and cognitive bias (Caputo, 2013).

External factors affecting decision-making include technological factors (Kauffman et al., 2013), political and legal conditions (Child et al., 2010), and consumer competition and demand (Ghafelehbashi et al., 2013). Changes, uncertainties, and new environmental conditions are perceived as risks and consequently affect the strategic trade-offs to mitigate risk factors (Shrader et al., 2000). Studies conducted by Zajac et al. (2000) indicates a clear linkage between specific environmental forces, such as high interest rates, and organizational resources such as decreasing competence, and strategic decision making through dynamic strategic appraisal modeling. Study conducted by Abele et al. (2004) specifically examines the importance of time effects in strategic decision making. According to researchers, in certain situations people tend to make different decisions when making decisions in conditions without having prior knowledge. The results of studies show that different cognitive processes either increase or decrease the focus on others in mediation by the effects of time.

Literature in economics and organizational theory explains the characteristics of decision-making approaches that emphasize bounded rationality. Rationality refers to the character of purposefulness and forwardlooking human actions, so that in a typical ideal sense, human actions must always be rational, in other words one must have good reason to explain what they are doing. They must have motivations, use the reason (good or bad) to respond to motivation and achieve their goals. Rational approaches to decision making (within organizations and markets) are still widely adopted among neoclassical economists and used implicitly in microeconomic standards to predict the behavior of economic agents. An empirical approach to rationality is to try to learn how the behavior of decisionmakers is successful. Behavior of decision makers is related to the tastes of 
decision makers who can change. In economic jargon, the decision-making appetite is represented by the decision makers' function. Changes in preferences can be explained by the acquisition of new information about the consequences of the actions that underlie the decision maker.

\subsection{Strategic Decision Making in Crisis}

The development of business environment towards economy globalization resulted in more competitive and complex business competition faced by organization. Organization stability is not only determined by internal factors, but also more influenced by external factors. The instability of business environments in industry and even the influence of economic activities abroad can trigger a crisis that may be faced by organization. This circumstances lead organization to formulate the right strategy to survive in the existing business competition.

Decision-making in time of crisis needs to take into account crisis management that includes various factors or factors that influence the choice of strategy. Muller (1985) article entitled "Corporate Crisis Management" as cited in Roberts (2015) suggests that there are six factors that decision makers need to consider in making the strategic decisions in time of crisis. The six key factors in crisis management include: management effectiveness, transformational leadership style, employee work motivation, conflict management effectiveness, and the concept of restructuring. The effectiveness of management can be created from within the company itself and strengthened by outside parties such as consultants, bankers, professional crisis managers who work under organizational leadership.

Leadership in time of crisis has two main functions: 1) ensuring the cooperation and motivation of management and employees through appropriate management leadership styles, and 2) improving management's ability to overcome critical restructuring within organization through appropriate organizational and personnel changes. Under these conditions, the transformational leadership model that has proactive, radical and not conservative thinking, is more innovative and creative, and open to new ideas. The role of leadership will affect the commitment of subordinates that transformational leadership needed especially in organization transition period. Active leadership is needed in creating organizational vision and empower all the organization members.

Employee motivation is an encouragement of attitudes, actions, and steps to achieve company mission by making effective efforts to produce performance in accordance with corporate objectives. High employee motivation in organization will result in valuable solution to overcome crisis. Conflict management is related to manage conflict that arise within the organization. Effective conflict management must be done thoroughly with regard to the causes of conflict and accept the aspirations of individuals or groups involved in the conflict, so that effective and efficient conflict resolution can be achieved and useful for improving organizational performance as the key to organizational success. Financial support from institutions and banks is essential in managing organizational crisis to decide whether companies will continue and close their businesses. The last factor to consider is the mastery and implementation of a realistic and sustainable concept of 
restructuring. This concept is needed to address strategic problems, operations, and liquidity within the organization.

Thompson (2007) suggests three strategies choices that can be used in time of crisis namely; turnaround strategy, immediate abandonment strategy or liquidation strategy, and end-game strategies. A turnaround strategy is needed when a business organization is in a state of crisis with the aim of retaining and sustaining sources of competitive advantage and addressing financial weaknesses as quickly as possible. Liquidation strategy is the last alternative for business organizations that are in crisis by getting out of the competition either by selling the company to another organization or closing the business. While end-game strategies are at the midpoint between turnaround strategy and end-game strategies emphasize in re-investment and take action to maximize cash flow in the short term to prepare out of the market.

Turnaround strategies

Turnaround strategy is needed when a business organization is in state of crisis with the aim of retaining and sustaining sources of competitive advantage and addressing financial weaknesses as quickly as possible. The main cause of problems in the business is to have too large debt, larger than expected potential sales growth, ignore the impact of corporate earnings decline, too aggressive attempt to buy existing market share by cutting very low prices, high fixed costs due to inability to use resource capacity efficiently, too optimistic about company's ability to penetrate new markets, too often to make strategic changes because previous strategies do not work well, and are overly influenced by competitors' strengths. The management task in facing such conditions is to formulate the right turnaround strategy to diagnose what is at the root of the problem of poor organizational performance. An understanding of what is wrong in business organizations and how serious the problem is important since different diagnoses will lead to different turnaround strategies.

Thompson (2007) put forward several actions that an organization can take under the circumstances, including: selling assets to increase cash flow to keep the remaining business, reviewing existing strategies, striving for increased revenue, striving for cost reductions, and using a combination of several businesses. Selling assets through an asset reduction strategy is important when cash flow is an important consideration and when the most practical ways to generate cash can be done through: 1) selling some of the company's assets (equipment, land, patents, inventories, and branches make a profit, 2) through retrenchment or reduce the marginal product of the product line, close or sell the old business.

A revised strategy is made when organizational weakness is caused by poor previous strategies. To revise may be used some alternatives include: 1) shifting new approaches to rebuild market positions, 2) improving internal operations and functional areas of strategy to better support overall strategy 3) mergers with other companies in the industry and use new strategies, 4) reduce core products and consumers closer to the strength of the company. Increasing revenue aims to generate increased sales volumes by cutting costs and remaining in BEP (Break Event Point) conditions when there is little operating cost; when improving 
profitability, companies can do by increasing their own usage capacity. Cutting production costs will work well when the company's value chain and cost structure are flexible enough. While the right combination of strategies performed on conditions that require fast action. A combination of strategies is done when managers are given full power to make important changes.

Liquidation strategy

Thompson (2007) argues that business in time of crisis conditions sometimes has resource that is not feasible and can not be saved, therefore there is no prospect of corporate profits if the business is still maintained. The best and most prudent solution is to close the business and liquidate the asset. Liquidation strategy is the last alternative for business organizations that are in crisis by getting out of the competition either by selling the company to another organization or closing the business. Initial liquidation efforts conducted in conditions of no hope to save the business, usually done better to serve the interests of shareholders than to overcome the inevitable conditions of bankruptcy.

\section{End-Game Strategies}

End-game strategies are at the midpoint between turnaround strategy and it emphasize reinvestment and taking action to maximize cash flow in the short term to prepare out of the market. This strategy is appropriately applied to businesses that are in the following circumstances: 1) when the business industry prospects in the long run are unattractive, 2) when business development requires too high cost or on marginal profitability, 3) when increased market share requires high cost to maintain, 4) when attempts to reduce the level of competition will not increase sales directly or quickly, 5) when companies can relocate available resources at higher opportunities, 6) when the business is not an essential core component of a company's business line overall, and 7) when the business does not contribute to other desired features such as good sales stability, prestige, and product lines. End games strategy is an effective strategy for a diversified company with a line or noncore business in a competitive position or an unattractive industry.

To determine the choice of the three alternative strategies proposed by Thompson (2007), the key factor to note is the assurance that the chosen strategy will ensure the effort to realize company's competitive advantage after going through a period of crisis through the choice of established strategy. This right is due to competitive advantage is the heart of corporate performance in competition market. Competitive advantage can be owned by the company if the company is willing and aware of the environment around changes and continue to adapt and motivate the strengths and opportunities that exist so that companies are able to minimize all the weaknesses and threats that exist from the corporate environment, so that the company has competitiveness than other competitors. The analysis and diagnosis of strategic advantage is a process whereby the strategist examines the corporate strategy's profit factors to determine where the strengths and weaknesses of firms, so that strategists can effectively utilize environmental opportunities and face environmental challenges (Kuncoro, 2005). If strategic decision makers are not fully aware of the strengths or benefits of strategies that the company will implement, then they can not choose the various environmental 
opportunities available for achieving company goals more successfully. Based on these considerations the strength or profit, weakness or risk factors, and the policies adopted in addressing the problem are the three main factors considered in the selection of strategies. Figure 1 shows the matrix that distinguishes the three strategies seen from these three factors.

The risk of applying a turnaround strategy refers to the study result conducted by Lohrke et al. (2004) which states that the implementation of turnaround strategy is a multi-phase process and requires response to prevent the occurrence of economic failure that requires high implementation costs. While the advantages or benefits of turnaround strategy refers to Hambrick and Schecter (1983) which states that the success of turnaround strategy related to efficiency and retrenchment improvements. The risks and advantages of applying the liquidation strategy refers to Kyle et al. (2006) that liquidity policy has a lower risk asset value than corporate balance sheet, but the company's liquidity policy can solve the problem of freight faster. The implementation of end-game strategy enables high exit risk cost if end-game strategy is unsuccessful but can provide benefits through increased profitability of the company if it is successful (Harrigan \& Porter, 2001).

Figure 1. Strategy Characteristics

\begin{tabular}{|c|c|c|c|}
\hline & Benefits & Risks & Policies \\
\hline Turnaround Strategy & $\begin{array}{l}\text { E ficiency improvement and } \\
\text { retrenchement } \\
\text { (H ambrick \&Schecter, } \\
1983 ; \text { Panicker \& } \\
\text { Manimala, 2015) }\end{array}$ & $\begin{array}{l}\text { High implementation cost } \\
\text { (Lohrke et al., 2004; } \\
\text { Panicker \& Manimala, } \\
2015)\end{array}$ & $\begin{array}{l}\text { Decrease in assets } \\
\text { Decrease in numbers of } \\
\text { employee } \\
\text { Changes in CEO } \\
\text { (Hambrick dan Scheder, } \\
\text { 1983; Panicker \& } \\
\text { Manimala, 2015) }\end{array}$ \\
\hline Liquidation Strategy & $\begin{array}{l}\text { Resolving bankruptcy } \\
\text { issues } \\
\text { (Kyle et al., 2006; Blair et } \\
\text { al., 2015) }\end{array}$ & $\begin{array}{l}\text { Company's assets is } \\
\text { lo ver than the company's } \\
\text { balance she et. } \\
\text { (Kyle et al., } 2006 \text {; Blair et } \\
\text { al., 2015) }\end{array}$ & $\begin{array}{l}\text { Close the business } \\
\text { Sell the companies } \\
\text { Kyle et al., 2006; B lair et } \\
\text { al., 2015) }\end{array}$ \\
\hline End-Game Strategy & $\begin{array}{l}\text { Increase pro fitability if } \\
\text { successful strategy } \\
\text { imple mentation } \\
\text { (Harrigan \& Porter, 2001; } \\
\text { Wie et al., 2011). }\end{array}$ & $\begin{array}{l}\text { The possibility of exit } \\
\text { costs is very high if the } \\
\text { im plem entation fails } \\
\text { (H arrigan \& Porter, 2001; } \\
\text { Wie et al., 2011). }\end{array}$ & $\begin{array}{l}\text { Maximization of cash flow } \\
\text { (Harrigan \& P orter, 2001; } \\
\text { Wie et al., 2011). }\end{array}$ \\
\hline
\end{tabular}

Source: Author elaboration 


\section{RESEARCH METHOD}

\subsection{Research Objects and Data Collection}

Data are collected from population using full-profile short card that provides information about the attributes of each strategy evaluated by the respondents. Data collected from students of Master Management Program, Faculty of Economics, Widya Mandala Catholic University, Surabaya. Purposive sampling are used as collection method for population that has been first determined by the researcher intentionally (Singh, 1986). The purposive sampling method used based on the consideration that the research model is tested on the respondent representing certain characteristics, Master of Management student is considered to have a good understanding of the process in strategic decision making.

\subsection{Conjoint Analysis Procedures}

Conjoint analysis is one of the approaches in multivariate analysis using dependency method aimed to know the influence or predict the value of the dependent variable based on more than one independent variable that influence. Conjoint analysis is based on respondent subjectivity to some combination of features offered (Green and Wind (1973) and Rao (1977) in Priem (1992). The consumer's subjectivity is measured through rank or score (Likert Scale). This analysis provides a quantitative measure of the relative importance of an attribute to another attribute of product (goods / services). In strategic management, conjoint analysis is implemented as a decision-making method under certain conditions (Priem, 1992).

Hair (2004) suggests several benefits of using conjoint analysis; 1) To determine the optimal combination of product attributes that are most important or appealing to the consumer, 2) Demonstrate the relative contribution of each attribute and level to all product evaluations affecting consumer purchasing process, 3) Group markets based on consumer likes similarity to product attributes. Conjoint analysis has advantages over other consumer preference analyzes such as consumer attitude index analysis because conjoint analysis is able to produce a combination of product attributes, while consumer attribute index analysis only produces a variety of product attributes only.

The empirical study of conjoint analysis applications in strategic management was undertaken by Rotaris (2000) in his working paper entitled "Innovation Strategies and Conjoint Analysis" which aimed at analyzing innovative decision-making processes and measuring the ability of corporate managers to innovate. This study contributes in analyzing the potential and limitations of conjoint analysis methodology as a tool for innovative decision-making processes within organizations. The study suggests the need for larger samples from some sample characteristics such as firm size, industry sector, and geographic location with the aim of collecting data from a representative sample to make predictions about future innovation strategies, and assist decision makers to encourage internal innovation process spontaneously. Another suggestion is the need to verify that each of the larger samples has different attitudes toward innovation decisions since each has specific characteristics. This study uses laboratory experiments by taking 
samples from a population using a full-profile short card that provides information about the attributes of each strategy evaluated by the respondents. The result of the data obtained from the respondents was analyzed using conjoint analysis through the stages as described in Figure 2.

The initial phase of conjoint analysis focuses on designing stimuli, with a number of objectives to determine which attributes or key factors will be examined further, setting levels and combinations between factors of each stimuli level, and devising a mathematical model for stimuli. According to Gudono (2011), the concept of conjoint measurement needs to be understood to know how the respondent's preference for the attributes of an object, in this study is a strategy, in shaping the size of one's utility over an object. To know the effect of the combined (joint effect) stimulus is done through Partworth Function invitation with the formula:

$$
\operatorname{Pref}(X)=\sum_{i=1}^{m} \sum_{j=1}^{k i} \alpha_{i j} X_{i j}+\varepsilon
$$

$\operatorname{Pref}(\mathrm{X})=$ The total utility of each stimuli

$\mathrm{a}_{\mathrm{ij}}=$ the contribution of an attribute level to the level of preference and respondent utility

$\mathrm{k}_{\mathrm{i}} \quad=$ the number of levels used for each factor

$\mathrm{m}_{\mathrm{j}}=$ number of factors used

$\mathrm{X}_{\mathrm{ij}}=1$ if the stimulus is $\mathrm{j}$ level attribute $\mathrm{i}$

After adjusting the scale of the formula changes to:

$$
U(X)=\sum_{i=1}^{m} \sum_{j=1}^{k i} \alpha^{\prime} X_{i j}+\varepsilon
$$

Therefore, in this study Partworth Function is determined as follows:

$$
\begin{aligned}
U= & \beta_{1} \operatorname{Risk}_{1}+\beta_{2} \text { RiskX }_{2}+\beta_{3} \text { Risk } X_{3}+\beta_{4} \text { Ben } X_{1}+\beta_{5} \text { Ben } X_{2}+\beta 6 \text { Risk } X_{3}+\beta_{7} X_{1}+\beta_{8} X_{2} \\
& +\beta_{9} X_{3}
\end{aligned}
$$


Figure 2. Research Stages Using Conjoint Analysis

\begin{tabular}{|c|c|}
\hline Stage 1 & $\begin{array}{l}\text { Identify Attributes or Factors and Sub Attributes or Levels } \\
\text { Objectives: } \\
\text { - To know the factors needed and desired in the process of strategic } \\
\text { decision making in time of crisis conditions. } \\
\text { - Specify sub attributes }\end{array}$ \\
\hline Stage 2 & $\begin{array}{l}\text { Method: } \quad \text { Selecting a Scenario } \\
\text { - Reduction with SPSS Orthoplan program } \\
\text { Objective: } \\
\text { - Define the selected scenario }\end{array}$ \\
\hline Stage 3 & $\begin{array}{l}\text { Method: } \\
\text { Determining Respondent Preference } \\
\text { - Through full-profile short card } \\
\text { Objectives: } \\
\text { - To know attributes and sub attributes and sub attributes that are liked } \\
\text { and disliked by respondents }\end{array}$ \\
\hline Stage 4 & $\begin{array}{l}\text { Method: } \\
\text { - Conjoint Analysis with SPSS Program } \\
\text { Objective: } \\
\text { - To determine what type of strategy typology is preferred in crisis } \\
\text { conditions and most influential in strategy selection. }\end{array}$ \\
\hline
\end{tabular}

\section{DATA ANALYSIS}

\subsection{Respondent Profile}

This study involved 20 respondents of the third semester students at Master of Management Program, Faculty of Economics, Widya Mandala Catholic University Surabaya. The detail characteristics of respondents are described in Table 1. Based on Table 1, it is known that most of the respondents participated in this study are female by $60 \%$, the majority of those aged between $20-25$ years $(55 \%)$, almost all of whom had a recent $\mathrm{S} 1$ educational background (95\%), the majority have work experience ranging from 1 to 5 years, and among the respondents have different profession as supervisor, banking officer, accounting manager, human resource manager, marketing, lecturer, graphic designer, purchasing manager, and assistant manager. 
Table 1. Respondent Profile

\begin{tabular}{llcc}
\hline & Characteristics & Amount & Percentage \\
\hline Gender & Male & 8 & 40 \\
Age & Female & 12 & 60 \\
& $20-25$ yo & 11 & 55 \\
& $26-30$ yo & 5 & 25 \\
& $31-35$ yo & 2 & 10 \\
Last Education & $36-40$ yo & 1 & 5 \\
Working Experience & $>40$ yo & 1 & 5 \\
& S1 & 19 & 95 \\
& S2 & 1 & 5 \\
& No working experience & 3 & 15 \\
& $1-5$ years & 8 & 40 \\
6-10 years & 4 & 20 \\
Posision & 11-15 years & 1 & 5 \\
& 16-20 years & 2 & 10 \\
& >20 years & 2 & 10 \\
& Supervisor & 2 & 10 \\
& Banking officer & 1 & 5 \\
& Accounting Manager & 1 & 5 \\
& Marketing & 3 & 15 \\
& Lecturer & 2 & 10 \\
& HR Manager & 1 & 5 \\
& Assistant Manager & 1 & 5 \\
& Graphic Designer & 1 & 5 \\
& Purchasing & 1 & 5 \\
None & 7 & 35 \\
\hline
\end{tabular}

Source: Data Processed

\subsection{Attitude towards Factors Affecting Strategic Decision Making}

Discussion on respondents' attitudes toward factors influencing strategic decision making in choosing the strategies to be implemented in time of crisis conditions is prepared in accordance with the stages in the conjoint analysis. Stages of conjoint analysis as discussed in the research methods are as follows:

1. Stimuli Design

At this stage, the first step is to determine attributes or factors and levels for each factor. Factors used in this study include risk, benefit, and policy. Levels for each factor in this study are presented in Table 2 which explains the definition of each factor and level for each factor. 
Table 2. Attribute or Factor and Sub Attribute or Strategy Level

\begin{tabular}{|c|c|c|}
\hline No. & FACTORS & LEVEL \\
\hline 1 & $\begin{array}{l}\text { Risk } \\
=\text { Risks that may arise from } \\
\text { the implementation of } \\
\text { strategy implemented }\end{array}$ & $\begin{array}{l}\text { 1. High implementation cost } \\
\text { 2. The value of company's assets is lower than the } \\
\text { company's balance sheet } \\
\text { 3. High possible exit costs }\end{array}$ \\
\hline 2 & $\begin{array}{l}\text { Benefit } \\
=\text { Benefits perceived by the } \\
\text { company when implementing } \\
\text { the chosen strategy }\end{array}$ & $\begin{array}{l}\text { 1. Improved efficiency and retrenchement } \\
\text { 2. Solving bankruptcy problems } \\
\text { 3. Increase profitability if strategy implementation } \\
\text { is successful }\end{array}$ \\
\hline 3 & $\begin{array}{l}\text { Policy } \\
=\text { The way or action taken by } \\
\text { the company when } \\
\text { implementing the chosen } \\
\text { strategy }\end{array}$ & $\begin{array}{l}\text { 1. Reorganized } \\
\text { (through decreasing assets, decreasing number of } \\
\text { employees, and changing CEO) } \\
\text { 2. Get out of the competition } \\
\text { (Closing the business or selling the company) } \\
\text { 3. Reinvestment } \\
\text { (Maximization of cash flow) }\end{array}$ \\
\hline
\end{tabular}

Source: Authors Elaboration

Table 3. Strategy Attributes Combination

\begin{tabular}{|c|c|c|c|c|}
\hline & Card ID & Strategy Risk & Strategy Benefit & Strategy Policy \\
\hline 1 & 1 & High exit cost & $\begin{array}{l}\text { Solving bankruptcy } \\
\text { problems }\end{array}$ & Out of the competition \\
\hline 2 & 2 & High exit cost & Efficiency improvement & Reinvestment \\
\hline 3 & 3 & Lower asset value & $\begin{array}{l}\text { Solving bankruptcy } \\
\text { problems }\end{array}$ & Reorganized \\
\hline 4 & 4 & $\begin{array}{l}\text { High implementation } \\
\text { cost }\end{array}$ & Efficiency improvement & Reorganized \\
\hline 5 & 5 & Lower asset value & Efficiency improvement & Out of the competition \\
\hline 6 & 6 & $\begin{array}{l}\text { High implementation } \\
\text { cost }\end{array}$ & $\begin{array}{l}\text { Solving bankruptcy } \\
\text { problems }\end{array}$ & Reinvestment \\
\hline 7 & 7 & High exit cost & $\begin{array}{l}\text { Increase profitability if } \\
\text { successful }\end{array}$ & Reorganized \\
\hline 8 & 8 & Lower asset value & $\begin{array}{l}\text { Increase profitability if } \\
\text { successful }\end{array}$ & Reinvestment \\
\hline 9 & 9 & $\begin{array}{l}\text { High implementation } \\
\text { cost }\end{array}$ & $\begin{array}{l}\text { Increase profitability if } \\
\text { successful }\end{array}$ & Out of the competition \\
\hline $10^{\mathrm{a}}$ & 10 & High exit cost & $\begin{array}{l}\text { Solving bankruptcy } \\
\text { problems }\end{array}$ & Reorganized \\
\hline $11^{a}$ & 11 & Lower asset value & Efficiency improvement & Reorganized \\
\hline \multicolumn{5}{|c|}{ a. Holdout } \\
\hline
\end{tabular}




\section{Designing Scenarios}

At this stage, researcher determines the combination of factors at each level. Factors and levels combined using the orthogonal design processed with the SPSS Program resulted in 11 combinations of cards, of which 2 cards were holdouts which were the validation of the stimuli. Holdouts are used to cross validate by applying the expected model parameters from the sample experiments on the holdout (Gudono, 2011)

3. Data Collection through Full-Profile Short Card

Charging short cards is done using ranking method or factor priority rating. The ranking of these factors primarily indicates the level of respondent's preference for the combination of factors and levels that influence the respondents in choosing the strategy to be implemented in time of crisis experienced by the organization among the many strategies offered. Rank 1 represents a combination of factors that are most important to respondents and rank 11 represents a combination of factors that are considered least important.

4. Determine what typology of strategy is much preferred in time of crisis conditions and most influential in the selection strategy.

To determine what type of strategy is preferred in time of crisis and the most influential strategy in this study can be seen from the overall statistic score. Through conjoint analysis, we can also known what kind of strategy typology is preferred by each of the respondents in time of crisis and most influential strategy. As an example, for respondent 1 the statistical analysis shows that for respondent 1 , policy attribute is the most important feature in strategic decision making to determine the choice of strategy that will be implemented in time of crisis condition with important value 62,693. The fitness model measured by Pearson's R (=983\%) and Kendall's Tau $(=957 \%)$ indicates that each attribute used is significantly considered in determining the preference for the choice of strategy to be implemented under crisis conditions. In terms of each attribute assessed by the consumer, it can be concluded that the risk of high implementation cost is considered most meaningful $(U=1,000)$, the benefit of efficiency improvement is the most important attribute $(U=1,000)$, and the reorganization policy is the chosen policy $(U=3,000)$. 
Table 4. Utility Value for Respondent 1

\begin{tabular}{|c|c|c|c|}
\hline \multicolumn{4}{|c|}{ Utilities } \\
\hline & & $\begin{array}{c}\text { Utility } \\
\text { Estimate }\end{array}$ & Std. Error \\
\hline \multirow[t]{3}{*}{ RISK } & High implementation cost &,- 667 & $\overline{4}, 471$ \\
\hline & Lower asset values & 1,000 & ,471 \\
\hline & High exit cost &,- 333 & ,471 \\
\hline \multirow[t]{2}{*}{ BENE IT } & Effficiency improvement & 1,000 & ,471 \\
\hline & $\begin{array}{l}\text { Problem solving for bankruptcy } \\
\text { Increasing profitability if success }\end{array}$ & $\begin{array}{l}-, 667 \\
-, 333\end{array}$ & $\begin{array}{l}, 471 \\
, 471\end{array}$ \\
\hline \multirow[t]{3}{*}{ POLII ' } & Reorganized & 3,000 & 471 \\
\hline & Out of competition & $-2,667$ & 471 \\
\hline & Reinvestment &,- 333 & ,471 \\
\hline (Cons int) & & & 333 \\
\hline
\end{tabular}

Table 5. Important Values for Respondent 1

Importance Values

\begin{tabular}{|l|l|}
\hline RISK & 18,519 \\
BENEFIT & 18,519 \\
POLICY & 62,963 \\
\hline
\end{tabular}

Table 6. Correlation Value for Respondent 1

\begin{tabular}{|c|c|c|}
\hline \multicolumn{3}{|c|}{ Correlations ${ }^{\mathrm{a}}$} \\
\hline & Value & Sig. \\
\hline Pearson's R & ,983 &, 000 \\
\hline Kendall's tau & ,957 &, 000 \\
\hline Kendall's tau for Holdouts & 1,000 & \\
\hline
\end{tabular}

a. Correlations between observed and estimated preferences

Based on the overall statistic score, policy attribute is the most important feature when compared to the other two features of risk and benefit as the basis of the decision maker's decision in determining the choice of strategy. This is indicated by the important value of 43.484 , while the risk of 27,446 , and the benefit of 29,069 . 
Table 7. Overall Utility Values

Utilities

\begin{tabular}{|ll|r|r|}
\hline RISK & Utigh implementation risk & $\begin{array}{c}\text { Utily } \\
\text { Estimate }\end{array}$ & Std. Error \\
& Lower asset value &,- 700 &, 642 \\
& High exit cost &, 550 &, 642 \\
BENEFIT & Efficiency improvement &, 350 &, 642 \\
& Problrm solving of &,- 583 &, 642 \\
& bankruptcy &, 642 \\
& Increasing &, 250 &, 642 \\
& Profitability if success & 1,567 &, 642 \\
POLICY & Reorganized & $-1,967$ &, 642 \\
& Out of competitition &, 400 &, 642 \\
& Reinvestment & 5,000 &, 454 \\
\hline
\end{tabular}

Table 8. Overall Important Values Importance Values

\begin{tabular}{|l|l|}
\hline RISK & 27,446 \\
BENEFIT & 29,069 \\
POLICY & 43,484 \\
\hline
\end{tabular}

Averaged Importance Score

Table 9. Overall Corellation Values

\begin{tabular}{|c|c|c|}
\hline \multicolumn{3}{|c|}{ Correlations ${ }^{\mathrm{a}}$} \\
\hline & Value & Siq. \\
\hline Pearson's R & ,929 &, 000 \\
\hline Kendall's tau & ,522 & ,028 \\
\hline Kendall's tau for Holdouts & 1,000 & \\
\hline
\end{tabular}

a. Correlations between observed and estimated preferences

The value of Pearson's $R=.929$ and Kendals Tau of .522 indicates that the attributes used are significantly considerate by the decision maker's to determine the strategic preferences that will be implemented in time of crisis conditions. Kendals Value Tau for holdout data $(1,000)$ shows Kendals Tau value without 
involving data from holdout sample. Based on the results of the assessment by the respondents for each attribute can be concluded that: the lower asset value risk is the most attention factor with utility value (.550), Benefit or efficiency improvement strategy is the most important factor considered in the selection strategy with utility value (.333), and reorganized policy is the most favored policy compared to the other two policies out of competition and reinvestment. This is shown through the important value of reorganization strategy of 1,567 .

\section{DISCUSSION AND CONCLUSION}

\subsection{Discussion}

The most important challenge for manager is how to survive in crisis. In time of crisis where the condition is characterized as time pressure, dynamic, and uncertainty, certain information can be difficult to access. The fundamental question to be answeres is how organization remain survive during the difficult time.This study conducted to analyze which strategy is preffered in time of crisis and what factors organization considered in choosing their strategy. Strategic decision making in time of crisis are classified based on study conducted by Thompson (2007) include turnaround strategy, liquidation strategy, and end-game strategy, while factors to be considered in choosing the optional strategy include benefits, risks, and policies regarding each strategy.

This initial study conducted to test the validity of the research instruments with Magister Management students as targeted respondents. Based on the data collected from 20 respondents, this study found that attributes of strategies are significantly considered to determine which strategy is preferend in time of crisis. From the risks attributes, specifically lower asset value become the most considered attribute by the decision maker in deciding strategy prefered in time of crisis. From the benefit attributes, efficiency improvement become the most important factor to be considered while from the policies attribute, the reorganized policy become the most prefered policy to consider in deciding what strategy to be implemented in time of crisis. Using the three alternative strategies in time of crisis which classified by Thompson (2007), it can be conclude that turnaround strategy is the most prefered strategy to respond the uncertainty during time of crisis.

The finding of this study support previous studies conducted by Rasheed (2005) and Tikici et al. (2011). In the context of small business, study conducted by Rasheed (2005) found that small business manager prefer growth strategy to retrenchment as turnaround strategy in time of crisis. It indicated that small business managers remain aggressive in time of crisis. Tikici et al. (2011) conducted studies involved manufacturing firms to determine whether turnaround strategy is implemented by those manufacturing firms to cope the global crisis and how their performance are affected as the consequence of their decision. This study found that turnaround strategy is implemented to cope the global crisis even not really high implemented. The finding also shown that there is positive medium strength linier relationship between turnaround strategy and organizational performance (Tikici et al., 2011). 
Beside the strategy attributes such as benefits, risks, and policies, there are still many factors to be considered in choosing the prefered strategy. Top management, as the decision maker need to consider factors both from internal and external organization. From the internal organization, factors like internal resources or firm specific capabilities should be considered (O' Regan et al., 2011). It can be explained from the resource-based theory, that when organization formulate strategy, they need to take advantage from their resources and capabilities, so that competitive advantage can be achieved (Barbero et al., 2012). In other words, organization need to use their internal resources and capabilities to respond the external environment which tend to be so volatile and unpredictable.

From the external organization, industry structure also need to be considered to decide the prefered strategy in time of crisis. According to Karmouchina et al. (2013), as the organization age grows, industry effect will stronger influenced the organization. It can be explained by the industry movement from heterogenous to standardize procedures to respond the crisis as described and explained through Porter's Generic Strategy (Porter, 2008). Porter (2008) explained that in term of industry life cycle, organization tend to against the forces (such as rivalry amongst existing competitiors, threath of new entrances, bargaining powers of suppliers and buyers, and threath of substitute product) that will imply organization to adopt their strategy to the external environment.

\subsection{Conclusion}

The results of study conducted to answer some research questions in determining the typology of strategy which is much preferred in time of crisis conditions and the most influential in the selection strategy resulted in several conclusions:

1. There are three important factors that influence the decision-making process by the respondents in choosing the strategy to be implemented in crisis condition that is: the usefulness of strategy implementation, the risk of strategy implementation, and the policy of strategy implementation.

2. Based on the results of the assessment by the respondents for each attribute can be concluded that: The lower asset value risk is the most considered factor with the utility value (.550), Benefit or efficiency of improvement strategy is the most important factor considered in the selection strategy utility value (.333), and reorganized policy is the most preferred policy compared to the other two policies: out of competition and reinvestment. This is shown through the important value of reorganization strategy of 1,567.

3. Referring to the three alternative strategies proposed by Thompson (2007) covering the turnaround, liquidation, and end-games strategy, then based on analysis of statistical data from the twenty respondents who participated in this initial study can be concluded turnaround strategy is preferred by respondents in responding crisis conditions facing by the company. This is seen from the analysis that the reorganization policy (which is the implementation of the policy of turnaround strategy) with the important value of 1,567 is the most chosen policy compared to the other two policies, out of competition and reinvestment. 
This studi has some implications both theoritical and practical implication. In term of theoritical implication, this study contribute to the development of strategic management studies especially topics related to strategic decision making in crisis. The use of conjoint analysis provide a significant contribution in the field of strategic management since conjoint analysis has been widely used in marketing research, and is still very rare implemented in the field of strategic management researches. In term of practical implication. This study findings can be considered for practitioners in making decisions related to strategy formulation and implementation in crisis as a platform for resolving problems through practical solutions which derived from policies and strategies implemented by the organization.

Since this study is an initial study to test the validity of the research instruments, it can be seen as the limitation of the study. Researchers acknowledge the number of sample, limited attributes to be considered, and the respondents selected has become the most weaknesses in this study. It is recommended that future studies should consider number of strategy attributes such as organizational resource and capabilities and industry structure in order to obtain information from the respondents regarding what attributes that influence them in decision making. Another factors to be considered from the external organization include culture and political condition. Future studies should determine the strategy that will be implemented in response to the condition crises faced by companies such as the role of internal factors (leadership and resources) and external factors (political conditions).

\section{REFERENCES}

Abele, S., Bless, H., \& Ehrhart, K-M., 2004. Social information processing in strategic decision-making: Why timing matters. Organizational Behaviour and Human Decision Processes, 93, pp.28-46.

Anatan, L., 2012. Aplikasi analisis konjoin dalam pembuatan keputusan strategik pada kondisi krisis. Working Paper-Research Issues in Strategic Management, Universitas Gadjah Mada Yogyakarta.

Barbero J.L., Casillas J.C., \& Feldman H.D., 2012. Managerial capabilities and paths to growth as determinants of high-growth small and medium-sized enterprises. International Small Business Journal, 29 (6), pp. 671-694.

Bamiatzi, V.C., \& Kirchmaier, T., 2014. Strategies for superior performance under adverse conditions: A focus on small and medium-sized high-growth firms. International Small Business Journal, 32 (3), pp.254-284.

Blair, J.W., Johnson, P.V., Duck, P.W., 2015. Analysis of optimal liquidation in limit order books for portfolios of correlated assets with stochastic volatilitAnalysis of optimal liquidation in limit order books for portfolios of correlated assets with stochastic volatility. Working Paper, The University of Manchester. 
Buller, J., 2014. Change leadership in higher education: a practical guide to academic transformation. Jossey-Bass Higher and Adult Education. San Francisco.

Burns, A., \& Harrison, M. C., 1979. A test of the reliability of psychographics. Journal of Marketing Research, 26(1), pp.32-38.

Calabretta, G., Gemser, G. \& Wijnberg, N.M., 2017. The interplay between intuition and rationality in strategic decision making: A paradox perspective, Organization Studies, 38 (3-4), pp.365-401.

Caputo, A., 2013. A literature review of cognitive biases in negotiation processes. International Journal of Conflict Management, 24 (4), pp.374398,

Child, J., Elbanna, S., \& Rodrigues, S., 2010. The political aspects of strategic decision making. The Handbook of Decision Making, Paul C. Nutt and David Wilson (eds.), Chichester: Wiley (2010).

Dabic, M., Tipuric, D., \& Podrug, N., 2015. Cultural differences affecting decisionmaking style: a comparative study between 4 countries. Journal of Business Economics and Management, 16(2), pp.275-289.

Eisenhardt, K.M., 1989. Building theories from case study research. The Academy of Management Review, 14 (4), pp.532-550.

Fredrickson, J. W., \& Mitchell, T. R. 1984. Strategic decision processes: Comprehensiveness and performance in an industry with an unstable environment. Academy of Management Journal, 27, pp.399-423.

Fox, J. 2015. From "economic man" to behavioural economics, Harvard Business Review, 5, pp.79-85.

Ghafelehbashi, S., Asadollahi, A., \& Nikfar, F., 2011. Acquaintance with all types of involvement in consumer behavior. Interdisciplinary Journal of Contemporary Research in Business, 3 (5), pp.493-507

Gudono, 2011. Analisis Data Multivariat. BPFE Yogyakarta.

Gu Seo, M., \& Barret, L.F., 2007. Being emotional during decision making-good or bad? An empirical investigation. Academy of Management Journal, 50 (4), pp.923-940.

Hambrick, D.C., \& Schecter, S.M., 1983. Turnaround strategies for mature industrial product business units. Academy of Management Journal, 26 (2), pp.231248.

Harrigan, K.R., \& Porter, M.E., 2001. End-game strategies for declining industries, Third New International Dictionary, pp.111-120. 
Kauffman, R.J., Liu, J., \& Ma, D., 2013. Technology investment decision-making under uncertainty: the case of mobile payment systems. System Sciences (HICSS), 2013 46th Hawaii International Conference on Support System. 710 Jan. 2013, Wailea, Maui, USA.

Karniouchina, E., V., Carson, S., J., Short, J., C., \& Ketchen Jr., D., J., 2013. Extending the firm vs. industry debate: does industry life cycle stage matter? Strategic Management Journal, 34 (8), pp.1010-1018.

Kuncoro, M., 2006. Strategi: Bagaimana Meraih keunggulan kompetitif. Penerbit Erlangga, Jakarta.

Kyle, A.S., On-Yang, H., \& Xiong, W., 2006. Prospect theory and liquidation decisions. Journal of Economics Theory, 139, pp.273-288.

Lilja, M., Sundberg, C., \& Sundberg, G., 2015. Growth strategies in declining industries. Thesis, Jonkoping University.

Lin, C., Tsai, H. L., \& Wu, J. C., 2014. Collaboration strategy decision-making using the Miles and Snow typology. Journal of Business Research, 67(9), pp.19791990.

Litvaja, I., Stancekovaa, D., 2015. Decision - making, and their relation to the knowledge management, use of knowledge management in decision - making, 23, pp.467-472.

Lohrke, F.T., Bedeian, A.G., \& Paler, T.B., 2004. The role of top management teams in formulating and implementing turnarounds strategies: a review and research agenda. International Journal of Management Review, 5/6 (2), pp.63-90

Maxwell, N.I., Rotz, D., \& Garcia, C., 2015. Data and decision making: same organization, different perceptions, Working Paper.

Mintzberg, H., 1975. The manager'sjob: Folklore and fact. Harvard Business Review, 53(4).

Mintzberg, H., 1981. 'What is planning anyway?' Strategic Management Journal, 2, pp. 319-324.

Morrish, J., 2012. Should you trust your gut feelings? Management Today, 54-57.

Nutt, P.C., 1992. Formulation tactics and the success of organizational decision making. Decision Science, 23, pp.519-540.

O’Regan, N., Kluth, C., Parnell, J., 2011. What Drives Firm Performance: Environment or Capabilities? Strategic Change, 20, pp.279-297.

Panicker, S., \& Manimala, M. J. (2015). Successful turnarounds: the role of appropriate enterpreneurial strategies. Journal of Strategy and Management, 8(1), pp.21-40. 
Parameswaran, R., 1979. Measuring reliability: a comparion of alternative techniques. Journal of Marketing Research, 16 (1), pp.18-25.

Papadakis, V.M., Thanos, I.C. \& Barwise, P., 2010. Research on Strategic Decisions: Taking Stock And Looking Ahead, in: Nutt, P.C. \& Wilson, D.C., Handbook of Decision Making, Chinchester: John Wiley, pp.31-70.

Pedhazur, E. J. \& Schmelkin, L. P., 1991. Measurement, design, and analysis: An integrated approach. Hillsdale, NJ: Lawrence Erlbaum Associates, Inc.

Pettigrew, A., 2003. Strategy as Process, Power and Change. In Cummings, S. \& Wilson, D. (Eds.) Images of Strategy. Blackwell Publishing.

Pettigrew, A. M. and McNulty, T., 1995. Power and influence in and around the boardroom. Human Relations, 48(8), pp.845-873.

Porter, M.E., 2008. The Five Competitive Forces That Shape Strategy. Harvard Business Review, 86 (1), pp.78-93.

Robinson, J., Sinclair, M., Tobias, J., \& Choi, E., 2017. More dynamic than you think: hidden aspects of decision-making. Administrative Science, 7, pp.1-29.

Roberts, I., 2015. The role of management in the turnaround process. Thesis, Manchester Business School.

Rotaris, L., 2000. Innovation strategies and conjoint analysis. Working Paper.

Schendel D, \& Hofer CW., 1979. Strategic management: a new view of business policy and planning. Little Brown: Boston, MA.

Shrader, C., Blackburn, V., \& Iles, P., 1997. Women in management and firm financial performance: an exploratory study, Journal of Managerial Issues, 9, pp.355-372.

Singh, J., 1986. Performance, slack, and risk taking in organizational decision making. Academy of Management Journal, 29, pp.562-585.

Smith, M., \& Graves, C., 2005. Corporate turnaround and financial distress. Managerial Auditing Journal. 20(3), pp.304-320.

Sommer, A., \& Pearson, C. M. (2007). Antecedents of creative decision making in organizational crisis: A team-based simulation. Technological Forecasting and Social Change: An International Journal, 74, pp.1234-1251.

Staw, B.M., Sandelands, L.E., Dutton, J.E., 1981. Threat-rigidity effects in organizational behavior: a multilevel analysis. Administrative Science Quarterly 26 (4), pp.501-524.

Tansey, P., \& Spillane, J., 2016. From crisis to opportunity: turnaround strategies of large Irish construction contractors during the period 2007-2015. In 
Proceedings of the 32nd ARCOM Annual Conference, 2016 (pp. 269-278). ARCOM.

Thomas, H., 1984. Strategic decision analysis: applied decision analysis and its role in the strategic management process. Strategic Management Journal, 5, pp.139-156.

Thompson, C. J., \& Troester, M., 2002. Consumer value systems in the age of postmodern fragmentation: the case of the natural health microculture. Journal of Consumer Research, 28(4), pp.550.

Wie, J., Wennlock, M., Johansson, D.J., A, \& Sterner, T., 2011. The fossil endgame: strategic oil price discrimination and carbon taxation. Working Paper, September 2011.

Wong, E.M., Ormiston, M.E., \& Tetlock, P.E., 2011. The effects of top management team integrative complexity and decentralized decision making on corporate social performance. Academy of Management Journal, 54 (6), pp.12071228.

Wu,T., Wu, Y.J., Tsai, H., Li, Y., 2017. Top management teams' characteristics and strategic decision-making: a mediation of risk perceptions and mental models. Sustainability, 9, pp.1-15

Zajac, E.J., Kraatz, M.S., Bresser, R.K.F. 2000. Modeling the dynamics of strategic fit: A normative approach to strategic change. Strategic Management Journal 21(4), pp.429-453. 